\title{
Unusual Neurological Manifestation of Proton Pump Inhibitor: A Case Report of Acute Disseminated Encephalomyelitis and Severe Hyponatremia After Brief Use of Proton Pump Inhibitor
}

\author{
Ahmad S. Qureshi ${ }^{1}$, Mohammad A. Quadri ${ }^{1}$, Babar Javed ${ }^{1}$ \\ 1. Critical Care Medicine, National Guard Health Affairs, Al Madinah, SAU
}

Corresponding author: Ahmad S. Qureshi, qures008@umn.edu

\begin{abstract}
Hyponatremia is commonly reported after the use of proton pump inhibitors (PPI). While omeprazole is most likely to cause hyponatremia, almost all the PPIs have been reported to cause hyponatremia. The underlying mechanism of PPI-induced hyponatremia is a syndrome of inappropriate antidiuretic hormone (SIADH) secretion which leads to hyponatremia. The hyponatremia can develop with only a few days of exposure to PPI. We present a case of a 56-year-old previously healthy female who was prescribed omeprazole for trivial acid reflux symptoms when she presented to the emergency room for evaluation of generalized weakness. She was discharged home from the emergency room after clinical evaluation as she had essentially normal lab work including a negative COVID PCR test. She subsequently developed progressive weakness of extremities and slurred speech over the next three days. She returned back to the emergency room and was found to have profound hyponatremia with MRI evidence of acute disseminated encephalomyelitis (ADEM). She was treated with hypertonic saline to correct hyponatremia and omeprazole was discontinued. The patient also received pulse dose steroids with improvement in her symptoms.
\end{abstract}

Categories: Internal Medicine, Neurology

Keywords: acute disseminated encephalomyelitis, omeprazole, hyponatremia, mri, female

Review began 05/21/2021 Review ended 06/02/2021 Published 06/10/2021

\section{() Copyright 2021}

Qureshi et al. This is an open access article distributed under the terms of the Creative Commons Attribution License CC-BY 4.0., which permits unrestricted use, distribution, and reproduction in any medium, provided the original author and source are credited.

\section{Introduction}

Drug-induced hyponatremia has been described with a number of medications including non-steroidal antiinflammatory drugs (NSAIDS), antipsychotics, selective serotonin reuptake inhibitors (SSRIs), and proton pump inhibitors (PPI) [1]. However, there are very few case reports of acute disseminated encephalomyelitis (ADEM) associated with drug-induced hyponatremia [2,3]. ADEM is acute inflammatory neurological disorders of several etiologies. Brighton collaboration has established case definitions for ADEM [4]. ADEM is diagnosed based on clinical and radiological abnormalities which are best seen on MRI imaging of the brain, brainstem, and spinal cord. MRI findings are best seen on T2 weighted images, fluid-attenuated inversion recovery (FLAIR) sequence, and Gadolinium contrast-enhanced images. MRI findings that raise suspicion for ADEM include deep white matter and subcortical lesion of variable size, location and symmetry involving the brain, brainstem and spinal cord. These disorders typically occur one to two weeks after bacterial, viral infections, or vaccination. In some patients, the presentation may be delayed up to three months [5]. Vaccine-induced ADEM has been associated with influenza, human papilloma virus (HPV), pneumococcal conjugate vaccine (PCV), rabies, diphtheria-tetanus-polio, smallpox, measles, mumps, rubella, Japanese B encephalitis, pertussis, and hepatitis B [6,7]. Pallegrino et al. reported that Flu and HPV were most commonly associated with ADEM and together accounted for one-third of cases $[7,8]$. We now report a case of ADEM related to the use of PPI Omeprazole that developed briskly and led to neurological deficits.

\section{Case Presentation}

A 56-year-old previously healthy female presented to the emergency room for evaluation for generalized weakness, body aches and pains as well as trivial acid reflux. Evaluation in the emergency room showed normal clinical examination and lab work including a negative COVID (PCR) test. She was discharged home on symptomatic management. She was prescribed omeprazole and acetaminophen as needed for intermittent acid reflux, body aches, and pain. Over the next four days, the patient developed progressive weakness of the lower extremities with slurred speech to the point that she needed assistance to ambulate. The patient reported poor appetite during this time. She denied polydipsia or excessive water intake. She did not report any impaired sensations, loss of bladder, or bowel control. These symptoms prompted her to return to the emergency room on the fifth day of her initial visit to the emergency department. The patient was alert, awake, and oriented. Vitals signs in the emergency room showed elevated initial blood pressure at 190/95 mm Hg (improved to 156/74 $\mathrm{mm} \mathrm{Hg}$ without any intervention), a pulse of 95 beats per 


\section{Cureus}

\begin{tabular}{|c|c|c|c|c|}
\hline $\begin{array}{l}\text { Laboratory } \\
\text { test }\end{array}$ & $\begin{array}{l}\text { Normal } \\
\text { values }\end{array}$ & $\begin{array}{l}\text { Initial emergency room } \\
\text { presentation (day 1) }\end{array}$ & $\begin{array}{l}\text { Subsequent emergency room presentation and } \\
\text { hospital admission on (day 5) }\end{array}$ & Comments \\
\hline $\begin{array}{l}\text { Serum } \\
\text { sodium }\end{array}$ & $\begin{array}{l}136-145 \\
\mathrm{mmol} / \mathrm{L}\end{array}$ & 137 & 116 & $\begin{array}{l}\text { Abnormal } \\
\text { (low) }\end{array}$ \\
\hline $\begin{array}{l}\text { Serum uric } \\
\text { acid }\end{array}$ & $\begin{array}{l}\text { 149-349 } \\
\text { umol/L }\end{array}$ & & 140 & \\
\hline $\begin{array}{l}\text { Random } \\
\text { cortisol }\end{array}$ & $\begin{array}{l}102-535 \\
\mathrm{nmol} / \mathrm{L}\end{array}$ & & 518 & \\
\hline Serum TSH & $\begin{array}{l}0.35 \sim 4.94 \\
\mathrm{mlU} / \mathrm{L}\end{array}$ & & 3.81 & \\
\hline Free T4 & $\begin{array}{l}9 \sim 19 \\
\mathrm{pmol} / \mathrm{L}\end{array}$ & & 15.03 & \\
\hline $\begin{array}{l}\text { Serum } \\
\text { osmolality }\end{array}$ & $\begin{array}{l}276-294 \\
\mathrm{mOsm} / \mathrm{kg}\end{array}$ & & 236 & $\begin{array}{l}\text { Abnormal } \\
\text { (low) }\end{array}$ \\
\hline $\begin{array}{l}\text { Urine } \\
\text { osmolality }\end{array}$ & $\begin{array}{l}301 \sim 899 \\
\mathrm{mOsm} / \mathrm{kg}\end{array}$ & & 700 & \\
\hline $\begin{array}{l}\text { Urinary } \\
\text { sodium }\end{array}$ & $\mathrm{mmol} / \mathrm{L}$ & & 64 & \\
\hline $\begin{array}{l}\text { Urinary } \\
\text { potassium }\end{array}$ & $\mathrm{mmol} / \mathrm{L}$ & & 36 & \\
\hline $\begin{array}{l}\text { Urinary } \\
\text { chloride }\end{array}$ & $\mathrm{mmol} / \mathrm{L}$ & & 89 & \\
\hline $\begin{array}{l}\text { CSF } \\
\text { appearance }\end{array}$ & Clear & & Clear & \\
\hline CSF protein & $0.15-0.4 \mathrm{~g} / \mathrm{L}$ & & 1.76 & $\begin{array}{l}\text { Abnormal } \\
\text { (elevated) }\end{array}$ \\
\hline CSF glucose & $\begin{array}{l}2.21-3.89 \\
\mathrm{mmol} / \mathrm{L}\end{array}$ & & 4.62 & $\begin{array}{l}\text { Abnormal } \\
\text { (elevated) }\end{array}$ \\
\hline CSF WBC & $\begin{array}{l}0 \sim 5 \times 106 \\
/ L\end{array}$ & & 1 & \\
\hline CSF RBC & $\begin{array}{l}0 \sim 10 \times 10 \\
6 / L\end{array}$ & & 7 & \\
\hline $\begin{array}{l}\text { CSF } \\
\text { segments }\end{array}$ & $0-6 \%$ & & $20 \%$ & $\begin{array}{l}\text { Abnormal } \\
\text { (elevated) }\end{array}$ \\
\hline $\begin{array}{l}\text { CSF } \\
\text { monocytes }\end{array}$ & $15 \sim 45 \%$ & & $64 \%$ & $\begin{array}{l}\text { Abnormal } \\
\text { (elevated) }\end{array}$ \\
\hline $\begin{array}{l}\text { CSF } \\
\text { lymphocytes }\end{array}$ & $40 \sim 80 \%$ & & $16 \%$ & $\begin{array}{l}\text { Abnormal } \\
\text { (low) }\end{array}$ \\
\hline COVID PCR & & & Negative & \\
\hline
\end{tabular}

TABLE 1: Pertinent laboratory test results 


\section{Cureus}

sequence images which did not show enhancement on contrast-enhanced T1 images with gadolinium (Figure 1). MRI of cervical, thoracic and lumbar spine were normal.

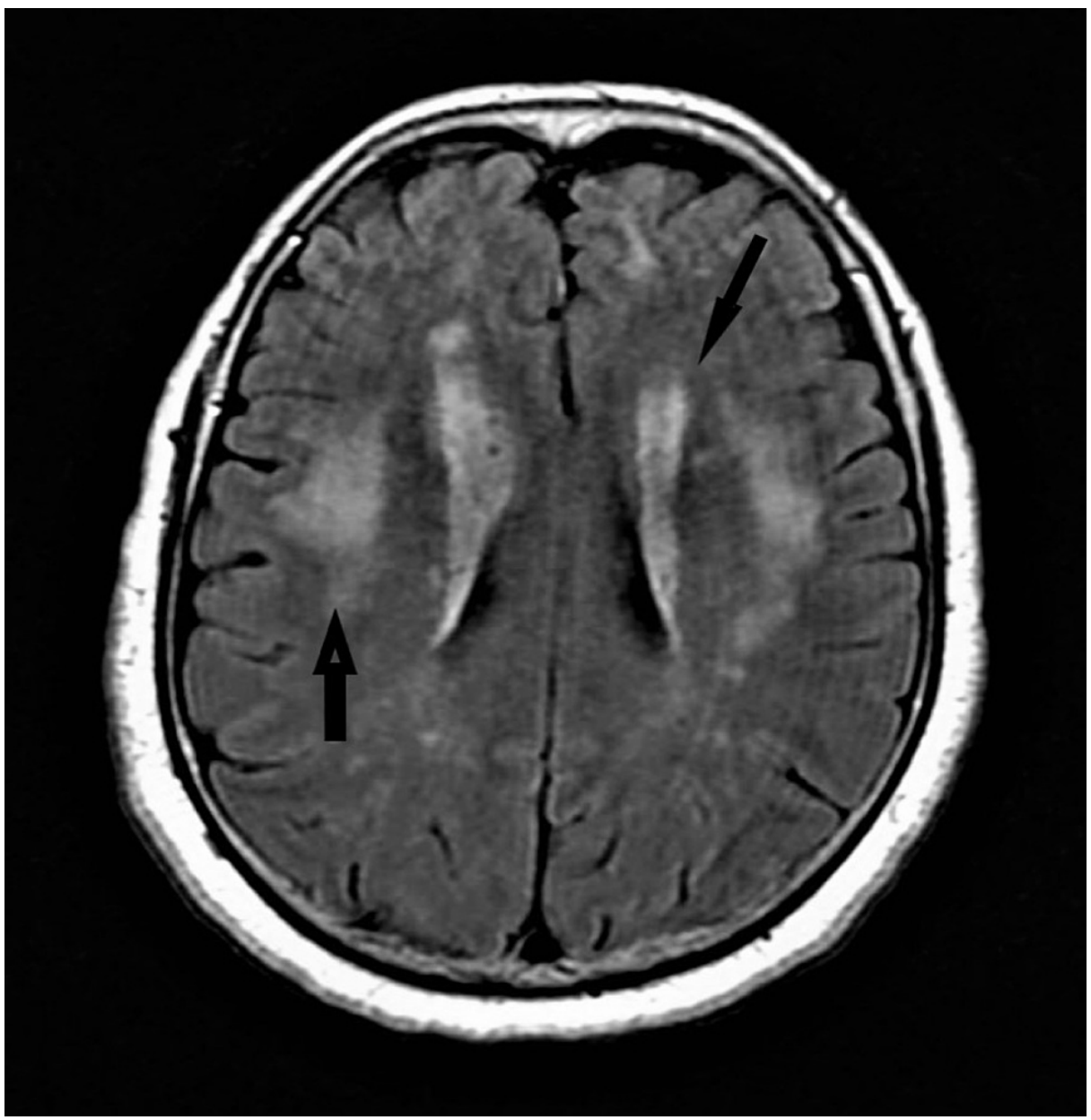

\section{FIGURE 1: MRI Brain showing patchy areas of asymmetric subcortical lesion on FLAIR sequence images (black arrows)}

The patient was treated with hypertonic saline $2 \%$ with very slow correction of serum sodium over the next 24 hours at the rate of less than $0.5 \mathrm{mEq} /$ hour. Subsequently, serum sodium improved to $133 \mathrm{mEq} / \mathrm{L}$ over one week. Serum uric acid also corrected to normal within 48 hours of admission. The patient had taken Omeprazole for four days prior to being admitted to the hospital and was discontinued on admission. The patient received pulse dose steroids using $1 \mathrm{~g}$ of methylprednisolone for five days along with physical and occupational therapy. This led to partial improvement of her weakness in lower extremities graded at $3 / 5$ at the time of discharge. The patient did not receive plasmapheresis or intravenous immune globulins (IVIG) during the course of the hospital stay.

\section{Discussion}

To the best of our knowledge, this is the first case report of omeprazole-induced hyponatremia presenting as ADEM. ADEM is multifactorial in etiology and the possibility of this being related to co-existing viral syndrome cannot be entirely ruled out. The patient did not take acetaminophen prescribed to her for symptomatic management of aches and pains. Hyponatremia associated with PPI use especially with omeprazole tends to occur with recent use and typically in elderly female patients. While there is no one MRI brain pattern that is diagnostic of ADEM, it is a combination of clinical suspicion and imaging that is helpful in establishing the diagnosis. ADEM is immune-mediated while MS is genetic in nature. ADEM affects children more often and has an acute onset and relatively good prognosis. On the other hand, multiple sclerosis (MS) tends to affect young adults with gradual onset but when it presents in children it can lead to significant disability over time. A follow-up MRI may be needed to distinguish it from MS as ADEM is, in general, a unimodal entity although in children a multimodal pattern like multiple sclerosis has been described. Mori et al. [2] have described a case of ADEM associated with hyponatremia related to the cerebral disease. However, ADEM is a rare complication associated with medication-induced hyponatremia [3]. Neurological manifestations such as dementia from long-term use of PPIs are well known which is attributed to amyloid protein deposition in neurons and vitamin B-12 deficiency [8,9]. Overall, the great 
majority of patients with ADEM show significant improvement in neurological deficits over a period of one to six months [10]. While correction of hyponatremia is imperative, for ADEM pulse dose steroids followed by prednisolone taper over subsequent four to six weeks is often needed. Other options for non-responders include IVIG and plasmapheresis [11-13].

\section{Conclusions}

Over the past several decades, PPI has become the preferred treatment for erosive esophagitis, peptic ulcer disease, and Helicobacter pylori infections. However, because of the easy availability of generic formulations over the counter, public access to this class of medication has also increased. While PPIs are potent acid suppressants, they are not free from serious side effects like electrolyte imbalances, risk for osteoporosis, and predisposition to Clostridium difficile infection, to name a few. This case report highlights the importance of recognizing the potential of PPIs to cause serious side effects like hyponatremia which can occur even with brief exposure to these medications. It also mandates that physicians recognize that patients who are taking PPIs may present with unusual or unexplained neurological findings, which may be related to the use of this class of medication. Additionally, it also highlights the importance of judicious use of such medications with close clinical follow-up, especially, in elderly females.

\section{Additional Information \\ Disclosures}

Human subjects: Consent was obtained or waived by all participants in this study. Conflicts of interest: In compliance with the ICMJE uniform disclosure form, all authors declare the following: Payment/services info: All authors have declared that no financial support was received from any organization for the submitted work. Financial relationships: All authors have declared that they have no financial relationships at present or within the previous three years with any organizations that might have an interest in the submitted work. Other relationships: All authors have declared that there are no other relationships or activities that could appear to have influenced the submitted work.

\section{References}

1. Correia L, Ferreira R, Correia I, et al.: Severe hyponatremia in older patients at admission in an internal medicine department. Arch Gerontol Geriatr. 2014, 59:642-7. 10.1016/j.archger.2014.08.002

2. Mori D, Nagayama I, Yamaguchi Y, Itano S, Imakita N, Takeji M, Yamauchi A: Hyponatremia associated with demyelinating disease of the nervous system. CEN Case Rep. 2013, 2:84-9. 10.1007/s13730-012-0047-9

3. Kaymakamzade B, Karabudak R, Kurne AT, Nurlu G: Acute disseminated encephalomyelitis after oral therapy with herbal extracts: a case report. Balkan Med J. 2016, 33:366-9. 10.5152/balkanmedj.2016.140420

4. Acute disseminated encephalomyelitis (ADEM): case definition pictorial algorithm . (2021). Accessed: March 5, 2021: https://brightoncollaboration.us/acute-disseminated-encephalomyelitis-adem-case-definitionpictorial-algorithm/.

5. Huynh W, Cordato DJ, Kehdi E, Masters LT, Dedousis C: Post-vaccination encephalomyelitis: literature review and illustrative case. J Clin Neurosci. 2008, 15:1315-22. 10.1016/j.jocn.2008.05.002

6. Shoamanesh A, Traboulsee A: Acute disseminated encephalomyelitis following influenza vaccination . Vaccine. 2011, 26:8182-5. 10.1016/j.vaccine.2011.08.103

7. Pellegrino P, Carnovale C, Perrone V, Pozzi M, Antoniazzi S, Clementi E, Radice S: Correction: acute disseminated encephalomyelitis onset: evaluation based on vaccine adverse events reporting systems. PLoS One. 2013, 8:696c2de4221e. 10.1371/annotation/1d544202-04f5-4848-83f1-696c2de4221e

8. Lam JR, Schneider JL, Zhao W, Corley DA: Proton pump inhibitor and histamine 2 receptor antagonist use and vitamin B12 deficiency. JAMA. 2013, 310:2435-42. 10.1001/jama.2013.280490

9. Zhang Y, Liang M, Sun C, et al.: Proton pump inhibitors use and dementia risk: a meta-analysis of cohort studies. Eur J Clin Pharmacol. 2020, 76:139-47. 10.1007/s00228-019-02753-7

10. Menge T, Hemmer B, Nessler S, et al.: Acute disseminated encephalomyelitis: an update. Arch Neurol. 2005, 62:1673-80. 10.1001/archneur.62.11.1673

11. Marchioni E, Marinou-Aktipi K, Uggetti C, et al.: Effectiveness of intravenous immunoglobulin treatment in adult patients with steroid-resistant monophasic or recurrent acute disseminated encephalomyelitis. J Neurol. 2002, 249:100-4. 10.1007/PL00007836

12. Keegan M, Pineda AA, McClelland RL, Darby CH, Rodriguez M, Weinshenker BG: Plasma exchange for severe attacks of CNS demyelination: predictors of response. Neurology. 2002, 8:143-6. 10.1212/WNL.58.1.143

13. Nishikawa M, Ichiyama T, Hayashi T, Ouchi K, Furukawa S: Intravenous immunoglobulin therapy in acute disseminated encephalomyelitis. Pediatr Neurol. 1999, 21:583-6. 10.1016/s0887-8994(99)00042-9 